\title{
IDENTIFYING COMPETITIVE STRATEGIES FOR EACH PHASE OF THE INTERMODAL TERMINAL LIFE CYCLE
}

\author{
Jason Monios ${ }^{1,2}$ and Rickard Bergqvist ${ }^{2}$ \\ ${ }^{1}$ Transport Research Institute, Edinburgh Napier University \\ Merchiston Campus, Edinburgh, EH10 5DT, United Kingdom \\ Email: j.monios@napier.ac.uk \\ ${ }^{2}$ Department of Business Administration, \\ School of Business, Economics and Law, Gothenburg University \\ P.O. Box 610, SE 40530 Gothenburg, Sweden \\ Email: rickard.bergqvist@handels.gu.se
}

This is the pre-published version of the text. The final published paper can be found at:

Monios, J., Bergqvist, R. (2017). Identifying competitive strategies for each phase of the intermodal terminal life cycle. Research in Transportation Business \& Management. 23: 97105.

DOI: $10.1016 /$ j.rtbm.2017.02.007

\begin{abstract}
This paper applies the marketing strategy literature to the four phases of the intermodal terminal life cycle (ITLC) to identify the appropriate competitive strategy to be undertaken at each phase, based on fluctuating markets and competitor behaviour. Not only can applying the correct strategy at each phase help to obtain a competitive advantage, but anticipating future strategies in advance can underpin the success of current strategies and ensure that both public and private stakeholders are prepared for future challenges.

The paper derives the appropriate strategies, provides empirical examples and discusses the opportunities and challenges inherent in each strategy. The paper concludes with suggestions for future research on strategy options that go beyond the traditional view of terminals as homogeneous interchangeable assets. Rather than simple improvement of factor conditions by investing in the infrastructure, innovative strategies to obtain competitive advantage should focus on partnerships with external stakeholders such as rail operators, 3PLs and shippers.
\end{abstract}

Key words: marketing strategy; business model; governance; intermodal freight transport; intermodal terminal; product life cycle 


\section{Introduction}

Research on intermodal transport operations and policy goals of modal shift from road to rail are based on certain assumptions and contexts which change throughout the life cycle of the terminal. Moreover, the accuracy of these assumptions depends on the interdependent relations between key stakeholders in the intermodal sector, for example the business model of the terminal, the KPIs and fees agreed in the terminal concession, the relationship between terminal operator and rail operators using the terminal and operational issues of wagon and locomotive management.

Monios and Bergqvist (2016a) applied the product life cycle (PLC) to intermodal terminals in order to establish a life cycle framework for situating analysis of intermodal terminal activities and strategies. This framework runs from the initial planning by the public sector, to the split in funding and ownership, selecting an operator, specifying KPIs, setting fees, ensuring fair access, and finally to reconcessioning the terminal, managing the handover and maintaining the terminal throughout its life cycle. This last point is especially important as industry conditions change and the terminal's role in the transport network comes under threat. Incumbent private operators are frequently reluctant to invest in old terminals, while public sector planners seek to maintain the quality of their national network. All of the phases throughout the terminal life cycle must be understood in order to provide a valid context to analysis of intermodal transport which provides input into government modal shift policy which itself is used to drive decisions on planning policy at all levels (local, regional and national) of government. Each phase of the intermodal terminal life cycle (ITLC) has certain key stakeholders and activities associated with it.

The focus of this paper is on deciding the appropriate competitive strategy for the intermodal terminal operator. The goal is to apply the marketing literature to the ITLC in order to identify the appropriate competitive strategy to be undertaken at each phase, based on 
fluctuating markets and competitor behaviour. A template for this approach was provided by Shaw (2012), who produced a framework linking the PLC with marketing strategies for each phase. Not only can applying the correct strategy at each phase be useful, but anticipating future strategies in advance can underpin the success of current strategies and ensure that the terminal is prepared for future challenges.

The following section introduces the competitive market in which intermodal terminals operate, drawing on Porter's Five Forces and Competitive Diamond as well as the resourcebased view. Section 3 describes the inductive methodology based on literature review and case examples and section 4 briefly recaps the main elements of the four phases of the ITLC. Section 5 applies the marketing literature to these four phases in order to identify the types of strategy relevant for each phase, which are then operationalised with empirical examples of each strategy. Section 6 discusses the issues arising from the application of each of these strategies in the intermodal sector. The final section draws conclusions related to the wider application of this framework and provides suggestions for further research.

\section{Competition, resources and strategy in the intermodal te rminal market}

In order to guide terminal strategy, it is first necessary to understand the terminal's role in the market. Wiegmans et al. (1999) used Porter's model of five competitive forces to consider the intermodal freight terminal market. They discussed barriers to entry and threats of substitute goods and which actors exercise power in the market. The industry competitors are other terminals operating within the local area, while potential entrants are new terminals that could be developed or perhaps old terminals re-entering the market. This is not normally a very immediate threat due to high entry barriers such as high investment costs, lack of market potential and lack of suitable locations; therefore, the threat of substitutes (i.e. road haulage) is far more serious and this is where the usual difficulty for intermodal transport lies. In terms of 
negotiating power, there is the negotiating power of suppliers, in this case the owner of the terminal facilities, if different from the operator. This is not always an issue as in many cases the operator is the owner or if not then they have a fairly stable relationship or concession with the owner, and both their interests are in alignment. The negotiating power of buyers is more often a challenge, usually rail operators bringing their trains to the terminals or 3PLs managing trains. There is also a second level of buyer power because the ultimate buyer of the transport service is the shipper, who will use road haulage if rail costs are too high or service quality too low, but these concerns are mediated through the rail operator or 3PL through whom the shipper contracts their transport services. If the terminal costs are too high or the service quality too low then the rail operator cannot ultimately provide attractive rail services to the shipper.

The appropriate strategy to adopt can also be derived through reference to the resourcebased view (RBV), which seeks ways to exploit asset specificity, whereby resources should be non-substitutable. Intermodal terminals are a fairly interchangeable resource unless they can offer better service or, ideally, more innovative and unique services. Thus Monios and Bergqvist (2016b) showed how moving from the resource-based view to the relational view can produce resource heterogeneity from an inter-firm relationship, for example a terminal integrating or collaborating with a rail operator and a shipper.

Ng and Gujar (2009) applied Porter's Competitive Diamond model to terminals, which is an updated version of the Five Forces. They argue that this model is more dynamic, moving beyond improving terminal operations by investment in factor conditions towards innovative strategies through which a terminal can differentiate itself from its competitors and even overcome deficits in factor conditions such as location or capital. As transport decisions and requirements become more integrated with the larger logistics strategy of terminal users, better customer focus and integrated solutions with rail operators can help terminals embed themselves more stably within a customer's supply chain. Cooperation with competitors and 
intensive marketing can also be applied, therefore using this lens reveals the importance of intermodal terminals taking a proactive stance on marketing strategy, rather than simply focusing on terminal efficiency and competing through price against broadly substitutable competitors. This kind of innovative strategy is captured by the value net model (Brandenburger and Nalebuff, 1996), which includes not just competitors, suppliers and customers but also complementors, which in this case would refer to an innovative strategy such as a terminal setting up a service in conjunction with a rail operator (e.g. sharing terminal equipment upgrading costs in exchange for traffic guarantees, providing maintenance and storage of wagons and locomotives) and working closely with a shipper (e.g. flexible opening hours of the terminal, flexible storage fees, detailed planning/preparation of chassis for preand post-haulage).

Sandberg (2013) showed that business models in logistics have internal and external components, and Monios (2015a) identified the internal and external governance relationships between intermodal terminals and logistic platforms, whereby the importance of external relationships with rail operators and ports were revealed to be of crucial importance in obtaining competitive advantage. These theoretical developments indicate that earlier models such as Porter and the RBV provide a sound basis but require increased nuance in their application to specific sectors. In order to be more specific about the kinds of strategies available to a terminal operator, it is necessary to understand that the terminal's needs and options change during its life cycle. This paper builds on the use of the product life cycle concept by Monios and Bergqvist (2016a) who identified the four phases of the intermodal terminal life cycle, by using the marketing literature to identify the kinds of strategies relevant at each phase. 


\section{Methodology}

This paper uses an inductive methodology, first to identify the relevant phases of the terminal life cycle and, second, to identify from an analysis of the literature and representative examples the appropriate marketing strategy for each phase. This paper is, therefore, to some extent a conceptual paper, nonetheless based on empirical examples. While cases from the authors' work and others published in the literature are given as examples of each strategy, the strategies cannot be induced solely from an analysis of such cases. The selection of cases is based on the premise that they provide good illustrations for the respective phases of the terminal life cycle. The aim of the paper is to identify and classify each strategy type, using brief empirical examples to demonstrate how these strategies are being applied in the intermodal sector, but space limitations preclude full case study analysis of all of the eight strategy examples.

One challenge arising from the many different frameworks under which intermodal terminals have been analysed in recent years is aligning the different focuses, from location studies and transport cost analyses to explorations of policy and planning issues. It is, therefore, not possible simply to compare strategies by quantitative analysis of the totality of cases in the literature. The issue is not whether $\mathrm{x} \%$ of terminals use strategy $\mathrm{y}$ or $\mathrm{x} \%$ use strategy $\mathrm{z}$. The goal is to use a sound theoretical basis to derive the framework of possible strategies which can then be used as the basis of understanding and comparing terminal actions, and as a basis for future research exploring individual strategies in more detail. That is why the framework must be structured according to the theoretical background from the marketing literature, where such strategies have been studied. Many of these issues derive from organisational complexity, conflicts in motivations between key stakeholders and changing governance forms between the development phase and the operational phase. This paper consolidates previous research and develops a researchagenda by identifying the key strategies within a new framework; future 
researchers can then focus on individual relationships that can aid the policy goal of increased modal shift to intermodal transport.

\section{The intermodal terminal life cycle (ITLC)}

This section provides a brief overview of the ITLC developed by Monios and Bergqvist (2016a). The product life cycle (PLC) concept has been influential for many decades and continues to appear in marketing textbooks. While it is a useful concept for description and education purposes, concerns exist regarding its ability to predict and forecast as well as guide strategic behaviour. The five stages of the PLC concept are development, introduction, growth, maturity and decline, and in its most basic form the shape of the curve is determined by sales plotted over time (Figure 1).

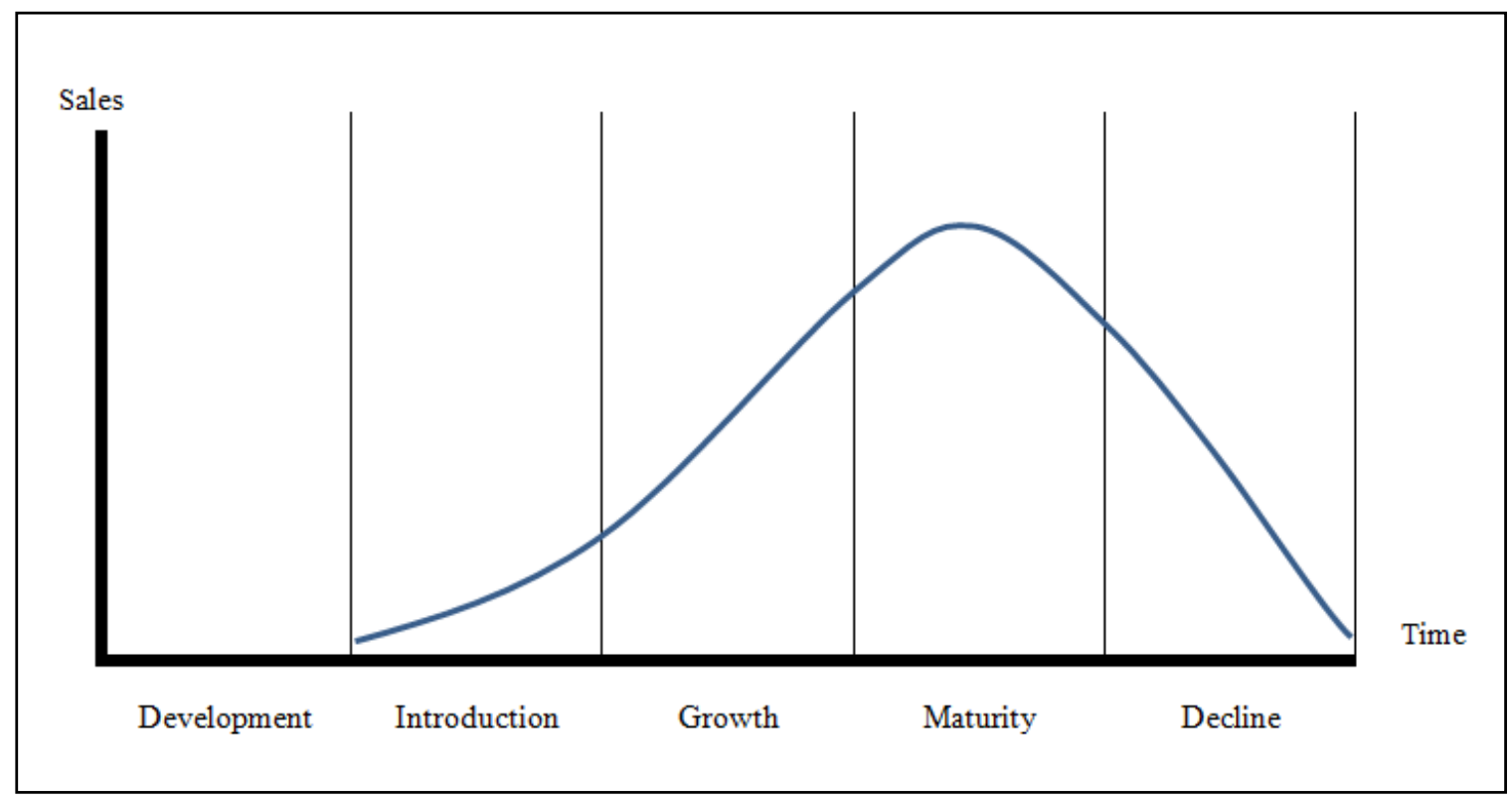

Figure 1. The product life cycle

Source: Authors, based on Kotler \& Armstrong (2012) 
When the PLC model was applied to ports by Charlier (1992), the port life cycle included a restructuring phase. Ports can restructure in various ways, such as deepening and lengthening berths and adding more and larger cranes to accommodate larger vessels, they can expand the size of the terminal if space permits, etc. They can also restructure by "location splitting", as argued by Cullinane and Wilmsmeier (2011); in such a strategy, the development of a satellite terminal in the hinterland can extend the port's operational limits and commercial reach when challenged by inadequacies of the existing port location, increasing competition or operational constraints. The PLC concept was applied briefly to inland ports in the United States by Leitner and Harrison (2001). They renamed the five stages as preparation, establishment, expansion, stabilization and reduction. They observed the influences on the reduction phase to be competition from other terminals as well as trends forcing operational changes.

The ITLC takes account both of the PLC model as well as previous applications to ports and inland ports. Regarding the identification of stages as well as their duration and major influences, the most pertinent to the early stages of intermodal terminals according to Day (1981) are the comparative advantage of the new product, the risk to the buyer, barriers to adoption and information availability. As time progresses, positive influences include the lowering of costs due to industry advances as well as changes to complementary (e.g. cranes) and substitute (e.g. road haulage) products. The role of competition is also substantial (e.g. nearby terminals, competing rail services).

In later stages, while marketing and information provision remain essential aspects of the intermodal terminal life cycle, they are less crucial than in the traditional PLC concept, because issues such as brand saturation, consumer acceptance and search for novelty are not relevant. Repeated purchases of intermodal transport services are more likely once the service has successfully reached maturity than with other consumer products. Intermodal transport retains its appeal primarily through standardisation and reliability. Once it is an established part of a 
shipper's transport chain, an intermodal terminal can expect continued sales, and decline is more likely to result from operational difficulties, infrastructure problems and changes in the market that move supply and demand to other locations.

The adapted PLC for intermodal terminals is based on the concerns raised in the literature regarding the difficulty distinguishing between phases with certainty as well as identifying and measuring the main influences. Therefore, the adapted model is not based on unit sales. A model could be constructed based on traffic over time, but the purpose of this model is to guide strategy, which relates to another criticism of the generic PLC model's inability to differentiate clearly between phases. Consequently, the phases of the life cycle in this model are based on observable phases of development and operation rather than on container throughput (Table 1).

For the case of intermodal terminals, the development phase in the original PLC is expanded to cover the planning, funding and development of a terminal. In the case of transport infrastructure there is an observable process of planning approval and identifying stakeholders and funders from the public and private sectors. The introduction phase in the traditional PLC in this case relates to finding an operator for the terminal, including the choice of business model and the role of the terminal in the overall transport network.

Table 1 . The intermodal terminal life cycle framework

\begin{tabular}{|c|c|c|c|}
\hline Product & Port & Inland port & Intermodal terminal \\
\hline Development & & Preparation & Planning, funding \& development \\
\hline Introduction & & Establishment & Finding an operator \\
\hline Growth & Growth & Expansion & \multirow{2}{*}{ Operations and governance } \\
\hline Maturity & Maturity & Stabilization & \\
\hline Decline & Ageing & \multirow{2}{*}{ Reduction } & \multirow{3}{*}{ Extension strategy } \\
\hline & Obsolescence & & \\
\hline & Restructuring & & \\
\hline
\end{tabular}

Source: Adapted from Monios \& Bergqvist (2016a) 
The growth and maturity phases in the original PLC model are merged into one because, regardless of sales, the issues relating to operations remain basically the same. If maturity for an intermodal terminal can be defined, as for ports, as "when it cannot provide more space to the customer due to saturation or to impediments that stop further expansion" (Charlier, 2013; pp. 599-600), then this is the trigger to enter the fourth phase, defined here as "extension strategy", and incorporating various strategies of restructuring physically, operationally and institutionally. The point of "maturity", then, is not a phase but a trigger for restructuring, which, if successful, will lead to another period of success until the next challenge arises.

The extension strategy phase is based on the restructuring phase from the port life cycle by Charlier (1992). Transport infrastructure can be upgraded and service portfolios developed to meet changes in the market; on the other hand, the infrastructure will also need to be maintained or simply monitored for long periods of time. Where a regular product or service on the market will simply be withdrawn and cease to be manufactured/offered due to absence of demand, transport infrastructure cannot be removed so easily. Public sector bodies will need to decide what to do with such infrastructure and consider whether it should be retained in the public stock or the land redeveloped for another purpose. The key features of each phase of the ITLC are summarised in Table 2. 
Table 2. Main features of each phase of the intermodal terminal life cycle (ITLC)

\begin{tabular}{|c|c|c|c|c|}
\hline & $\begin{array}{l}\text { Planning, funding \& } \\
\text { development }\end{array}$ & Finding an operator & Operations \& governance & $\begin{array}{l}\text { Long-term or extension } \\
\text { strategy }\end{array}$ \\
\hline Length & $3-10$ years & $1-2$ years & >10years & $>15 y e a r s$ \\
\hline $\begin{array}{l}\text { Main } \\
\text { stakeholders }\end{array}$ & $\begin{array}{l}\text {-Public infras tructure } \\
\text { stakeholders (e.g. rail } \\
\text { authorities, planners, etc.) } \\
\text {-Large shippers } \\
\text {-Real es tate developers } \\
\text {-Terminal operator } \\
\text {-Rail operators } \\
\text {-Ports }\end{array}$ & $\begin{array}{l}\text {-Public infras tructure } \\
\text { owner } \\
\text {-Terminal owner (if } \\
\text { different to the above) } \\
\text {-Terminal operator }\end{array}$ & $\begin{array}{l}\text {-Public infras tructure owner } \\
\text {-Terminal owner (if different } \\
\text { to the above) } \\
\text {-Terminal operator } \\
\text {-Rail operators }\end{array}$ & $\begin{array}{l}\text {-Public infras tructure } \\
\text { owner } \\
\text {-Other public stakeholders } \\
\text { (e.g.rail authorities, } \\
\text { planners, etc.) } \\
\text {-Terminal operator }\end{array}$ \\
\hline $\begin{array}{l}\text { Main activities } \\
\text { undertaken }\end{array}$ & $\begin{array}{l}\text {-Planning } \\
\text {-Design } \\
\text {-Funding sought } \\
\text {-Tendering of construction } \\
\text {-Construction }\end{array}$ & $\begin{array}{l}\text {-Designing business \& } \\
\text { ownership model } \\
\text {-Tendering for operator } \\
\text {-Designing concession } \\
\text { agreement } \\
\text {-Contract development }\end{array}$ & $\begin{array}{l}\text {-Continuous improvements } \\
\text {-Responding to changes in } \\
\text { technology \& demand }\end{array}$ & $\begin{array}{l}\text {-Renewed terminal } \\
\text { concession } \\
\text {-Potential changes in } \\
\text { business \& ownership } \\
\text { model } \\
\text {-Potential expansion } \\
\text {-Ensuring long-term } \\
\text { strategy and control } \\
\text {-Potential sale \& } \\
\text { redevelopment of site for } \\
\text { new purpose }\end{array}$ \\
\hline
\end{tabular}

Source: adapted from Monios and Bergqvist (2016a)

\section{Identifying the competitive strategies from the marketing literature}

This section first analyses the marketing strategies provided by Shaw (2012) for each of the four phases of the PLC in order to map them across to the appropriate phases of the ITLC. Empirical examples of each strategy are then provided, which are discussed and then summarised in Table 3.

The marketing literature is focused on the operational life of the business, therefore does not address the PLC development phase. However, the strategies suggested by Shaw (2012) as appropriate to the introduction phase actually straddle both of the first two phases of the intermodal terminal life cycle, as they are intrinsic to the reason for developing the terminal in the first place. The strategy alternatives are penetration or niche. Penetration (Dean, 1951; Ansoff, 1965) pursues an aggressive marketing mix for a mass market or a large market 
segment, while niche (Kotler, 1980; Porter, 1980; McCarthy, 1981) targets a specific market segment. In most situations, a niche strategy is more appropriate for an intermodal terminal than a penetration strategy. The inherent limitations of rail provision, such as its lack of flexibility and responsiveness compared to road transport, mean that only certain kinds of product flow are suitable for modal shift to rail. Yet penetration strategies are possible in new markets with unexploited potential.

The marketing strategies proposed for the PLC growth phase are segment expansion (Smith, 1956; Ansoff, 1957) and brand expansion (Taubler, 1981). The former aims to expand the marketing segment currently served, while the latter aims to add more choice or value through additional products or services. Both of these strategies can be applied to the third phase of the intermodal terminal life cycle.

As the maturity phase of the traditional PLC spans both the operational (phase three) and extension strategy (phase four) of the intermodal terminal life cycle, the maturity strategies advised by Shaw (2012) can be considered relevant to both of these phases. Shaw recognises that maturity is commonly managed via a maintenance strategy, but a strategy of differentiation (Smith, 1956; Porter, 1985, 1990) can be used in a more aggressive manner. These strategies overlap phases three and four of the intermodal terminal life cycle. Late during the PLC maturity phase Shaw (2012) notes that a harvesting strategy (Henderson, 1970; Kotler, 1978) is likely to become necessary. This involves reducing any marketing strategy to the bare minimum required to maintain profit as sales are predicted to decline shortly. During decline, the strategy progresses from harvesting to divesting. Therefore, both harvesting and divesting will be relevant to the intermodal terminal extension strategy phase. The next step is to operationalise the theoretically-derived marketing strategies by providing practical examples of each of the relevant strategies (summarised in Table 3). 
Table 3. Empirical examples of each strategy

\begin{tabular}{|c|c|c|c|}
\hline Strategy & Phase & Description & Case example \\
\hline Penetration & $1 / 2$ & $\begin{array}{l}\text { Aggressive marketing for a large market, likely } \\
\text { to be a proactive operator developing a terminal } \\
\text { to meet an identified demand. Less likely in a } \\
\text { mature in termodal sector like Europe but more } \\
\text { likely in a developing intermodal market. }\end{array}$ & $\begin{array}{l}\text { Hidalgo, Mexico: a new terminal developed by a port } \\
\text { operator to capture a previously road-based market } \\
\text { (Wilms meier et al., 2015). }\end{array}$ \\
\hline Niche & $1 / 2$ & $\begin{array}{l}\text { Customised service based on vertical integration, } \\
\text { inclusion of 3PL, open book arrangement. }\end{array}$ & $\begin{array}{l}\text { Jula/Schenker, Falköping Sweden: open-book } \\
\text { collaboration between a shipper and a 3PL to es tablish } \\
\text { a container shuttle provided a long term contract and } \\
\text { allowed the terminal owner to invest (Monios and } \\
\text { Bergqvist, 2015a). }\end{array}$ \\
\hline $\begin{array}{l}\text { Segment } \\
\text { expansion }\end{array}$ & 3 & $\begin{array}{l}\text { Invest and upgrade the terminal to encourage } \\
\text { traffic growth through increased modal shift. }\end{array}$ & $\begin{array}{l}\text { BNSF Chicago Joliet terminal: huge inland port } \\
\text { development to support Far East imports for big box } \\
\text { retailers (Rodrigue et al., 2010). }\end{array}$ \\
\hline $\begin{array}{l}\text { Brand } \\
\text { expansion }\end{array}$ & 3 & $\begin{array}{l}\text { Expand service offering, storage, maintenance or } \\
\text { a more tailored integrated model in volving rail } \\
\text { operators and 3PLs. }\end{array}$ & $\begin{array}{l}\text { DIRFT, Daventry, UK: Centralised inland hub for } \\
\text { retailer imports expanded to anchor development of } \\
\text { secondary rail distribution to Scotland (Monios, } \\
\text { 2015b). }\end{array}$ \\
\hline Maintenance & $3 / 4$ & $\begin{array}{l}\text { In phase } 3 \text {, this is the standard intermodal } \\
\text { strategy, maintaining current customers with } \\
\text { little opportunity to capture new traffic due to the } \\
\text { fixed nature of the sector (i.e. market is limited } \\
\text { by inherent constraints of the mode). In phase } 4 \text {, } \\
\text { maintenance leans towards harvesting, e.g. } \\
\text { sweating the assets. }\end{array}$ & $\begin{array}{l}\text { Riyadh, Saudi Arabia: Large terminal serving a capital } \\
\text { city with several direct port shuttles per day } \\
\text { (Bergqvist, 2013). }\end{array}$ \\
\hline Differentiation & $3 / 4$ & $\begin{array}{l}\text { In phase } 3 \text {, this is similar to brand expansion: } \\
\text { offering added value. In phase } 4 \text {, it may involve } \\
\text { a change of offering, perhaps linked to a new } \\
\text { concession with a better operator. }\end{array}$ & $\begin{array}{l}\text { ADIF PLAZA Zaragoza, Spain. ADIF were running } \\
\text { the terminal themselves but it wasn't successful so } \\
\text { they concessioned it to a consortium led by port } \\
\text { terminal operator Noatum (Garcia-Alonso et al., } \\
\text { 2016). }\end{array}$ \\
\hline Harvesting & 4 & "Cash cow", sweating the assets. & $\begin{array}{l}\text { Freightliner, Coatbridge, UK: Ex-public sector } \\
\text { terminal with 40-year old cranes (Monios \& } \\
\text { Wilmsmeier, 2012). }\end{array}$ \\
\hline Divesting & 4 & $\begin{array}{l}\text { Exiting the market and closing or selling the } \\
\text { terminal. }\end{array}$ & $\begin{array}{l}\text { Azuqueca, Spain: was a small terminal running for a } \\
\text { few years but couldn't grow the business due to short } \\
\text { distance and fragmentation of flows (Monios, 2011). }\end{array}$ \\
\hline
\end{tabular}

Hidalgo, Mexico (Wilmsmeier et al., 2015) is an example of penetration, whereby a new intermodal terminal was developed by a port terminal operator (global operator HPH) to secure its hinterland by capturing a previously road-based market. Additional benefits were achieved by the improved cargo security on the rail shuttles compared to road transport. The niche strategy is represented by the case of Jula/Schenker (Monios and Bergqvist, 2015a), which is an open-book collaboration (equivalent to a cost-plus contract) between a shipper and a 3PL to establish a container shuttle between the port of Gothenburg and the inland terminal in Falköping Sweden. This setup provided a long-term contract and allowed the terminal owner 
to invest, demonstrating the benefits of working closely with the shipper to reduce transaction costs and make intermodal transport economically competitive.

Segment expansion is based on traffic growth through increased modal shift, exemplified by the large inland port development by rail operator BNSF at their Chicago Joliet terminal (Rodrigue et al., 2010). This strategy was aimed at supporting Far East imports for big box retailers, thus securing large scale growth at the terminal. Brand expansion relies on new services and integration of the terminal within supply chains, represented by Daventry International Rail Freight Terminal (DIRFT), Daventry, the busiest intermodal terminal in the UK (Monios, 2015b). This centralised inland hub for retailer imports was expanded twice to facilitate growth and anchor development of secondary rail distribution to local DCs in Scotland, backloaded with domestic flows from Scottish suppliers into the Midlands NDCs (National Distribution Centre).

A maintenance strategy is the standard approach to intermodal terminal management, maintaining current customers with little opportunity to capture new traffic segments due to the fixed nature of the sector (i.e. the market is limited by inherent constraints of the mode). In phase 4, maintenance leans towards harvesting, e.g. sweating the assets. Both strategies are represented by the very large inland terminal at Riyadh, Saudi Arabia, handling over 300,000 TEU loaded inbound containers annually, with the same number of mostly empty containers moved back to the port of Dammam (Bergqvist, 2013). This is a large terminal and the only site serving a capital city with several direct port shuttles per day and a lack of room to expand, thus sweating the assets is the only option until a decision can be made on expanding the terminal or providing an additional terminal to split the cargo.

In phase 3, the differentiation strategy is similar to brand expansion, based on offering added value. In phase 4, however, it is more likely to involve a change of offering, perhaps linked to a new concession with a better operator. The large logistics platform PLAZA in 
Zaragoza, Spain has an adjacent intermodal terminal developed by national rail operator ADIF (Garcia-Alonso et al., 2016). ADIF were running the terminal themselves but it was not very successful in attracting container movements from ports, so they decided to alter the market positioning of the terminal by concessioning its operation to a consortium led by port terminal operator Noatum. The harvesting strategy is common in ex-public sector terminals developed in a very different market situation. This strategy is exemplified by the Coatbridge terminal owned and operated by Freightliner, UK (Monios \& Wilmsmeier, 2012). Specialising in port container shuttles since the early days of containerisation, this ex-public sector terminal was part of the management buyout when the company was privatised in the 1990s. Upgraded equipment is sorely needed but low margins mean that senior management are reluctant to make the necessary large investment with a long payback period. Finally, a divesting strategy occurs when a firm exits the market and either closes or sells the terminal. A recent example is the small terminal at Azuqueca, Spain (Monios, 2011), which operated for a few years but had difficulty growing the business due to short distance and fragmentation of flows and has since ceased container traffic.

\section{Discussion of strategy selection at each phase of the intermodal terminal life cycle}

\subsection{Phase one: planning, funding and development}

Penetration strategies are generally appropriate to situations where the intermodal provider is not competing against road but rather competition exists between firms offering the same service. It is for firms with large resources, a large market of price sensitive customers, many potential competitors and few barriers to entry. Other than the last two requirements, this strategy could be considered more relevant for analysis of port or shipping competition, rather than intermodal transport. The given example of penetration (Hidalgo, Mexico) is in a developing country where the intermodal system is not yet mature. Thus a proactive developer 
can establish a new terminal to capture known demand that is currently going by road. It also helps if there are other factors that can encourage modal shift, in this case one of the main drivers being improved cargo security offered by rail shuttles, which proved a successful strategy. In mature intermodal markets such as Europe or the United States, pursuing a penetration strategy by developing a new large scale intermodal terminal is more difficult.

By contrast, a niche strategy requires a customised product and targeted marketing efforts aimed at a small customer base. Such characteristics can clearly be seen in the personal relationships and long preparation of intermodal operators and 3PLs establishing a new intermodal service for shippers using rail for the first time. An essential part of this mix is the terminal, but it is difficult for the terminal owner to make large investments (either to develop the infrastructure in the first place or to upgrade as required for new traffic) without firm commitment from the shippers or rail operators, who are rarely in a position to provide it. The example given in the previous section (Falköping, Sweden) was an open-book collaboration between a shipper and a 3PL to establish a container shuttle based on flexible provision of services such as storage and opening hours, and also included an unusually long term contract which allowed the terminal owner to invest in upgrading the terminal. Applying this strategy even in the development phase allows long term planning and a more suitably designed terminal with appropriate capacity. The niche strategy was very successful in this case, allowing a small terminal developed by the municipality to grow quickly with high confidence for future planning due to close ongoing stakeholder engagement. As we argue throughout the paper, this kind of customised service with vertical integration of operations is key to successful intermodal transport in most contexts.

The application of a niche strategy should already be in place during the planning and development phase of an intermodal terminal. Instances exist where public sector actors have funded or part-funded the development of a terminal without a realistic assessment of the 
market, not necessarily in absolute terms but in terms of that portion of the market that will realistically shift modes. In retrospect, many terminal developers make the mistake of unrealistic market assessments. The terminal requires the suitable location and geographical attributes in order to serve a market, but it also requires the ability to run services with suitable timings and capacity, in addition to offering handling at a low cost. Market studies are required and especially discussions with local shippers in order to obtain suitable levels of interest if not a definite commitment to use the terminal.

\subsection{Phase two: finding an operator}

Penetration and niche are relevant to both phases one and two of the intermodal terminal life cycle. As noted above, penetration strategies tend to be less relevant in the intermodal sector except in favourable circumstances where demand is high but no terminal currently exists. In such a case, there is likely to be demand from an active operator who would develop the terminal themselves or work with a public body throughout the planning phase and then become the operator themselves. A niche strategy, on the other hand, is likely to be driven by the public sector due to marginal demand that is not attractive enough to overcome the barrier to entry for private operators, as was the case in the Falköping example just discussed. For such a development, the strategy choice covers both phases one and two, because the developers should anticipate from early in the process that some kind of tender round will need to be conducted whereby an attractive concession package will need to be designed to incentivise an operator to take on the terminal. Subsidy may be involved, but it will need to be designed appropriately to encourage efficient operations that will attract and retain custom.

Designing such a concession contract is often difficult (Monios \& Bergqvist, 2015b), based on agreements regarding, for example, splitting storage fees between owner and operator, increasing or decreasing subsidy per container handled, new service development and 
responsibilities for promotion and marketing. Understanding the terminal's role in the market vis-à-vis competitors, its relationship with external stakeholders (e.g. whether the potential terminal operator has its own rail services or has a high degree of collaboration with certain rail operators) and its potential for segment or brand expansion (see next phase) are necessary in order to produce an appropriate concession contract and select a suitable concessionaire. The associated risks and costs must be factored in to the initial decision to develop a terminal, thus phase two strategy must already have been anticipated in phase one. Therefore, while the strategy option at this phase is perhaps straightforward on the surface, the importance lies in its relation with the previous and following phases. The ability to anticipate future changes can help ensure a better outcome of the strategy applied during this phase.

\subsection{Phase three: operations and contracts}

A segment expansion strategy is based on successfully persuading more firms to shift mode. As with the previous strategies, this can only be done in conjunction with rail operators. Once the terminal has been successfully introduced and some operators have established regular services, such expansion becomes possible. The example given in this paper is the large inland port development by BNSF at their Chicago Joliet terminal to support Far East imports for big box retailers, so the services to the terminal were underpinned by large regular demand. Developing a large site with high capacity both at the terminal and in surrounding logistics and warehousing facilities provided a basis for business development through segment expansion. This is because, due to the high fixed costs of rail operations, it is always easier to add new containers to an existing service that has already broken even than it is to establish a new service with uncertain profits. In order to serve this expanding market, expansion may be required at the terminal, by adding more tracks or extending current ones, adding new cranes 
or redesigning the terminal layout to improve efficiency, or improving management practices to ensure a smooth flow of traffic.

Such a strategy may, however, be challenged by two governance issues. The first governance issue relates to contractual difficulties (cf. Bergqvist \& Monios, 2014) whereby delays can be caused due to uncertainties regarding maintenance and so on. The second relates to the need for investment for expansion. Most intermodal terminals operate at close to the margin already, and if expansion is required then it can be very difficult to secure investment from the owner. Public sector owners are reluctant to invest more money, and in many cases if the terminal is privately owned then the owner may be a foreign investment company seeking regular reliable returns rather than pursuing an expansion strategy. In some ways a region may even be considered to be held to ransom by private terminal operators claiming they do not have a sufficiently sound business case to release funds from senior management, while the current terminal quality deficit is causing delays in traffic and constraining growth for the region. Some countries seek to overcome this stalemate through specific modal shift grants, but these are often for operations rather than infrastructure investment (cf. Monios, 2015b). In order to resolve such a strategic impasse, the business model of the terminal may be changed, with potentially a new concession contract based on a modified funding and pricing mix in order to lever in public money based on future earnings of the terminal. In such a case the terminal moves to the fourth phase of the life cycle where an entirely new business model and market placement is designed which eventually moves the terminal back to phase two. Therefore, it is important to understand as early as possible in the life cycle, but at least by phase three, that successful operations will lead to the desire to expand the market segment, which in many cases cannot be done under the same business model that was established during phases one and two, therefore it can be a good idea to anticipate such developments and where relevant build them into the initial concession contract. 
The next available strategy during the third phase of the ITLC is brand expansion. As already discussed in the niche strategy, intermodal terminals are a clear example of the need to offer value added services in order to attract new customers and to retain current ones, not just in simple terms of expanding the offer but even to construct a viable package in the first instance. The key to successful intermodal transport is integration of operations. A brand expansion strategy can add choice by offering new departure times or destinations, but service expansion is more likely. This can take the form of services at the terminal such as container storage, cleaning and maintenance or empty depot services. The example given above (DIRFT, Daventry, UK) is a centralised inland terminal for retailer imports in the UK, at a location where most large retailers have their NDCs located. In the past they distributed from here by road to regional DCs and to stores. The DIRFT terminal has expanded twice and key to this expansion has been development of secondary rail distribution to Scotland. This was developed over several years through close collaboration between a few large retailers, 3PLs acting as intermediaries and rail operators transporting the containers. Government modal shift subsidy was also involved as it is difficult to compete on cost with road at this distance. Through providing a tailored package through the collaboration of several stakeholders, this secondary rail corridor has proved a success and more users have since joined these services. The role of 3PLs to coordinate these flows has been instrumental to the scheme's success, providing an integrated logistics package whereby the terminal works with a forwarder or 3PL to manage flows, offer last mile trucking and provide real-time information on cargo location and condition throughout the transport chain. Intermodal terminals can also be used as buffers in the supply chain, allowing a customer to make larger orders but not need to store all the inbound goods at their own warehouse.

A maintenance strategy is very suitable to the intermodal market, which relies on maintaining existing customers rather than seeking many new customers, due to the often rather 
static nature of the market and the service. Indeed, during phase three this is the standard intermodal strategy, maintaining current customers with little opportunity to capture new traffic due to the fixed nature of the sector (i.e. the market is limited by inherent constraints of the mode). The example given above (Riyadh, Saudi Arabia) was of a large terminal serving a capital city with several direct port shuttles per day, but without room to expand therefore the focus is on managing an overcapacity terminal to the best of its ability and seeking new strategies from planners on additional terminals to handle increased flows.

A strategy of differentiation is less likely in intermodal transport, except when considered as merely a continuation of the brand expansion strategy just discussed, whereby the terminal offers added value where possible, usually in conjunction with a rail operator. Therefore, were a terminal operator to establish a new relationship with a rail operator to bring a new service to the terminal, this could be considered a differentiation strategy. Equally, ending a concession and selecting a new terminal operator with better contacts or an integrated service portfolio could also be considered as differentiation, which is more relevant to the fourth phase. This was the case in the example given above (ADIF PLAZA Zaragoza, Spain), whereby the incumbent public terminal operator had not achieved the success they had hoped and decided to concession the terminal to a private operator. Interestingly, the selected operator was a consortium led by a port terminal operator, which provided the degree of vertical integration often necessary to a successful terminal. In this case, integrating with the port terminal anchored port flows from those ports which enabled a successful strategy of differentiation.

\subsection{Phase four: extension strategy}

Maintenance and differentiation strategies can be followed in both phases three and four. Given the difference in activities between the two phases, following these strategies during phase four tends to be more proactive as there is a pressing need during the extension phase to 
refocus the business model of the terminal due to changes in the market. Therefore when applied in phase four rather than phase three maintenance and differentiation strategies lean closer to the other two distinct strategies available during this phase: harvesting and divesting. For example, the decision on maintenance at this phase could be more about sweating the asset and obtaining the most from it with least investment rather than a genuine long-term maintenance strategy, while divesting may be not simply closing or selling a terminal but reconcessioning it.

It is not uncommon that the extension strategy phase will include renewing a terminal concession which may in some cases be allied to a change in ownership or business model, as in the ADIF example just discussed. This may then return the terminal back to phases two and three, starting again with a new operator with their own approach to the niche market and their own views on how to expand their segment or brand. So this kind of differentiation may be more proactive as opposed to a terminal that had followed a natural progression from phase one to two to three.

Shaw (2012) uses the term "cash cow" when describing the harvesting strategy, and there is no doubt that some intermodal terminals are managed according to this strategy. It is particularly evident in the case of terminals that were developed by the public sector in areas with a lack of competition and later privatised. Indeed, this is noticeable in many privatised industries, where the new owner simply sweats the existing assets until no more profit is possible. At this stage the asset can be abandoned or public support requested. As shown in the example provided above (Freightliner, Coatbridge, UK), an old terminal developed during the period of a nationalised rail operator and privatised in the 1990s is still using the same equipment and is in dire need of new funds. The strategy has been successful in the sense that the terminal continues to operate successfully and even attract some new traffic segments 
(some of the secondary retail flows discussed in the DIRFT example above), but is not ideal from a system perspective.

There is thus a clear link between the phases of maturity and decline (according to the traditional PLC) or operational phase and extension strategy phase (according to the ITLC). If the maturity phase is not handled correctly then decline will be the result, and indeed this relates back to the development phase. Public sector terminal developers need to be aware of the long life of intermodal terminals, and remain cognisant of the fact that such a phase will inevitably be reached and private operators or owners are unlikely to make large investments in transport infrastructure.

Shaw (2012) notes that, even in a declining market, a small number of providers may be able to survive by serving a niche market. This observation reveals the tension between harvesting and divesting in the ITLC, as, after losing larger traffic flows, some small terminals may be able to return to handling a regular small flow that is well suited to rail transport (e.g. a large local shipper with regular demand) and thus likely to continue using the terminal even if other factors change, for instance declining efficiency due to old equipment. The question is whether the operator continues to provide the service or chooses instead to divest. In such a case, the public sector needs to make a decision regarding the long-term strategy. Do they invest in upgrading the terminal, thus arresting a decline and underpinning long-term operation, do they allow the terminal to shut down but safeguard the site for future use, or do they allow the land to be sold for another use, thus losing the strategic site that cannot be replaced due to increasing development on strategic central sites resulting from other pressures such as need for housing. The example provided earlier (Azuqueca, Spain) was a small terminal running for a few years but was unable to grow the business due to short distance and fragmentation of flows so the operator exited the market. However, the terminal infrastructure remains in place and the site has a 45-year lease from the local authority, thus it is ready to be reactivated if a 
suitable business model with sufficient traffic can be established. That is why the fourth phase of the ITLC is considered as a long-term or extension phase, because regardless of the state of the market or the number of sales (which is the defining metric according to traditional PLC approaches), the terminal infrastructure remains in place and continues to require strategic decisions.

The choice of extension strategy links closely with decisions made at earlier phases, and can in some cases return the life cycle back to an earlier phase, analogous to the change in operator already discussed above which takes the terminal from phase three back to phase two. A change in ownership of a successful terminal severs the link with phases one (development) and two (concession to operator), as the terminal is no longer within the control of its original developers. This could therefore be considered a divesting strategy, in that the owner is divesting themselves of the asset, although the terminal remains in operation, and indeed the original owner may actually develop a new terminal (thus returning to phase one). It is not unheard of for a public sector owner to sell a successful terminal to its private operator and use the money to finance a new terminal. This situation highlights how the life cycle approach helps to guide strategy for terminal developers, by anticipating such potential scenarios and planning in advance how they would deal with them and under what conditions certain strategy decisions such as divesting will be made. This also guides investment from interested stakeholders as they can face the future with greater certainty.

\section{Conclusion}

The findings in this paper are relevant for academics, policymakers, planners and terminal managers. For academics, the strategic framework helps guide understanding and analysis, while for policymakers and planners it aids future planning. The framework also allows terminal managers to integrate their short-term operational decisions with the longer-term 
strategic and tactical focus of the other stakeholder groups. Overall, it allows all of these groups to coordinate their plans in an integrated manner. This leads to significant policy implications regarding terminal development, in which we include both high level policymakers and local transport and land-use planners. The ways in which the public sector supports the initial terminal development or subsidises later investments must be based on an integrated life cycle plan underpinning a long-term understanding of the terminal's changing market position throughout its life. Fundamental to the best use of this framework is to provide policymakers with a temporal perspective, the ability to anticipate future needs and thus reduce delays and uncertainties at key moments. The remainder of this section outlines the nature of these challenges and the aid to policymakers and planners that can be derived from the use of the framework.

While the analysis in this paper is focused on the intermodal terminal, the viability of an individual terminal is determined in large part by the economic viability and competitive performance of intermodal transport as a transport solution. Barriers to modal shift are well known and relate to issues such as distance, service quality, handling charges, asset utilisation and balancing traffic flows. These are the responsibility and concerns of the service providers rather than the terminal operator, but understanding of the terminal life cycle can provide input into interpreting such cost analyses. The economics of the intermodal terminal change over its life cycle. Business models, cost structures and charging principles defined in concession contracts strongly influence the prices charged by the operator to the terminal users and hence determine the ability of transport operators to attract shippers from road to rail. Understanding the business model and the contractual situation as it changes throughout the life cycle should improve the ability to construct the appropriate strategy at each phase for both public and private stakeholders. 
It is often the case that public investments are made in terminals based on feasibility studies incorporating analysis of traffic flows that may depend on who controls the traffic and their equipment and service requirements, or be determined by the role of local large shippers. The appropriate strategy adopted by the main stakeholders will be different in each case. While major decisions by stakeholders relate mostly to the development phase, changes throughout the life cycle such as selecting the initial operator or changing to another operator at a later time will affect the selection and success of such strategies.

The long-term phase or extension strategy of a terminal has not been addressed thus far in the literature. The value of the life cycle approach is to identify this phase as a strategic priority for terminal stakeholders at any phase, and to highlight particularly the importance of anticipating this phase during the development process. Optimistic stakeholders during the first phase are unlikely to consider whether and under what conditions they would sell the terminal in later years and how this position may change depending on whether the terminal is a success or a failure. Plans will not be put in place for needed investment and upgrades and institutions and personnel are highly likely to have changed by that time. Having such a strategy in place can be a major help to all stakeholders, particularly policymakers and planners who may otherwise have to make a strategic decision on needed investment without due preparation and warning.

This paper has focused on marketing strategies and market positioning, based on an understanding of the characteristics of terminal assets and how to obtain competitive advantage in what is to some degree a homogeneous market of substitutable terminals. Understanding that intermodal transport requires a niche strategy based on brand expansion through integration with rail operators can help the planning phase by anticipating such needs and building it into the concession contract, as well as anticipating the relevant cost structures that may require certain types of subsidies or indeed even disagreements over issues such as storage fees. Such 
anticipation should also enable the terminal planners to expect the need to expand the terminal through a segment expansion strategy and consider how this will be dealt with some years in the future. Likewise, the potential need to manage a declining terminal either through renewed investment, a new concession under a different business model or through closing down should also be anticipated early in the life cycle. Anticipating the likelihood of an operator sweating the asset through a harvesting strategy can enable public planners to expect the need for renewed investment or even perhaps a regulatory approach to incentivise operators to continue to maintain equipment and provide good service. Anticipating future strategies in advance can underpin the success of current strategies and ensure that the terminal is prepared for future challenges.

The crucial outcome of the above strategy analysis and the area where future research is required is that terminals should not be treated as interchangeable assets whose value is based only on their quality of handling derived primarily from investment. Rather, terminal success is built on innovative strategies to obtain competitive advantage by focusing on partnerships with external partners such as rail operators, transport service providers such as forwarders and hauliers, 3PLs and shippers. These relationships will be key to the terminal's viability at all four phases of its life cycle, and suitable strategies should be designed to encourage such activities. Therefore, when planners are designing a financial model during the first phase and a concession contract during the second phase, they should anticipate future investments, profit shares, risk and reward involving not just the terminal itself but the key external stakeholders. All strategies throughout the life cycle should be geared towards this essential need to position the terminal in the market, underpinning its ability to compete with road haulage, attract customers and hence achieve policy goals of modal shift. 


\section{References}

Ansoff, H. I. (1957). Strategies for diversification. Harvard Business Review. 35 (5): 113-24.

Ansoff, H. I. (1965). Corporate Strategy. New York, NY: McGraw Hill.

Bergqvist, R. 2013. Developing large scale dry ports - the case of Arriyadh. Journal of Transportation Technologies. 3 (3): 194-203.

Bergqvist, R. (2015). Hinterland Logistics and Global Supply Chains, in D-W. Song and P. Panayides (eds.), Maritime Logistics - A Guide to Contemporary Shipping and Port Management, 2nd edition, Kogan Page, pp. 67-88.

Bergqvist, R., Monios, J. (2014). The role of contracts in achieving effective governance of intermodal terminals. World Review of Intermodal Transport Research. 5 (1): 18-38.

Brandenburger, A., Nalebuff, B. (1996). Co-opetition. New York: Broadway Business.

Charlier, J. (1992). The regeneration of old port areas for new port uses. In: Hoyle B. S., Pinder D. A. (Eds.). European Port Cities in Transition. London, Belhaven Press, pp. 137-154.

Charlier, R. H. 2013. Life cycle of ports. International Journal of Environmental Studies. 70 (4): 594-602.

Cullinane, K. P. B., Wilmsmeier, G. (2011). The Contribution of the Dry Port Concept to the Extension of Port Life Cycles. In: Böse, J. W. (Ed.). Handbook of Terminal Planning. New York, Springer, pp.359-380.

Day, G. (1981). The product life cycle: analysis and application issues. Journal of Marketing. 45: 60-67.

Dean, J. (1950). Falling prices for new products. Harvard Business Review. 28: 45-53.

Dean, J. (1951). Managerial Economics. Englewood Cliffs, NJ., Prentice Hall.

Forrester, J. W. (1959). Advertising: a problem in industrial dynamics. Harvard Business Review. 37: 100-110. 
Garcia-Alonso, L., Monios, J., Vallejo-Pinto, J-A. (2016). Port competition through hinterland accessibility: the case of Spain. Paper presented at the International Association of Maritime Economists (IAME) annual conference, Hamburg, July 2016.

Henderson, B. D. (1970). The product portfolio. Perspectives. Boston, MA.: Boston Consulting Group.

Jones, C. (1957). Product development from the managerial point of view. In: Clewett, R.L. (Ed.). Marketing's Role in Scientific Management. Chicago, IL: American Marketing Association.

Kotler, P. (1978). Harvesting strategies for weak products. Business Horizons, August 1978, pp. $15-22$.

Kotler, P. (1980). Marketing Management: Analysis, Planning, Implementation and Control. Englewood Cliffs, NJ: Prentice Hall.

Kotler, P., Armstrong, G. (2012). Principles of Marketing. 14 ${ }^{\text {th }}$ ed. New Jersey: Prentice Hall. Leitner, J. S., Harrison, R. (2001). The Identification \& Classification of Inland Ports. Austin, TX: Centre of Transportation Research, University of Texas, Austin.

McCarthy, E. J. (1981). Basic Marketing: A Managerial Approach. Homewood, IL: Richard D. Irwin.

Monios, J. (2011). The role of inland terminal development in the hinterland access strategies of Spanish ports. Research in Transportation Economics. 33 (1): 59-66.

Monios, J. (2015a). Identifying governance relationships between intermodal terminals and logistics platforms. Transport Reviews. 35 (6): 767-791.

Monios, J. (2015b). Integrating intermodal transport with logistics: a case study of the UK retail sector. Transportation Planning and Technology. 38 (3): 1-28. 
Monios, J., Bergqvist, R. (2015a). Using a "virtual joint venture" to facilitate the adoption of intermodal transport. Supply Chain Management: An International Journal. 20 (5): 534548.

Monios, J., Bergqvist, R. (2015b). Intermodal terminal concessions: lessons from the port sector. Research in Transportation Business \& Management. 14: 90-96.

Monios, J., Bergqvist, R. (2016a). Intermodal freight terminals: a life cycle governance framework. Routledge: Abingdon.

Monios, J., Bergqvist, R. (2016b). Vertical integration in the rail sector: using wagons as “relationship specific assets.” International Journal of Logistics Management. 27 (2): 533 551.

Monios, J., Wilmsmeier, G. (2012). Port-centric logistics, dry ports and offshore logistics hubs: strategies to overcome double peripherality? Maritime Policy and Management. 39 (2): 207-226.

Ng, K. Y. A., Gujar, G. C. (2009). Government policies, efficiency and competitiveness: the case of dry ports in India. Transport Policy. 16 (5): 232-239.

Porter, M. (1980). Competitive Strategy. New York, NY: The Free Press.

Porter, M. E. (1985). Competitive Advantage: Creating and Sustaining Competitive Advantage. New York, NY: The Free Press.

Porter, M. E. (1990). The Competitive Advantage of Nations. New York, NY: The Free Press. Rodrigue, J-P., Debrie, J., Fremont, A., Gouvernal, E. (2010). Functions and actors of inland ports: European and North American dynamics. Journal of Transport Geography. 18 (4): 519-529.

Sandberg, E., 2013. Understanding logistics-based competition in retail - a business model approach. International Journal of Retail \& Distribution Management. 41 (3): 176-188.

Shaw, E. H. (2012). Marketing strategy: from the origin of the concept to the development of a conceptual framework. Journal of Historical Research in Marketing. 4 (1): 30-55. 
Smith, W. R. (1956). Product differentiation and market segmentation as alternative marketing strategies. Journal of Marketing. 20: 3-8.

Tauber, E. M. (1981). Brand franchise extensions: new products benefit from existing brand names. Business Horizons. 24 (2): 36-41.

Wiegmans, B. W., Masurel, E., Nijkamp, P. (1999). Intermodal freight terminals: an analysis of the terminal market. Transportation Planning \& Technology. 23 (2): 105-128.

Wilmsmeier, G., Monios, J., Rodrigue, J-P. (2015). Drivers for Outside-In port hinterland integration in Latin America: the case of Veracruz, Mexico. Research in Transportation Business \& Management. 14: 34-43. 